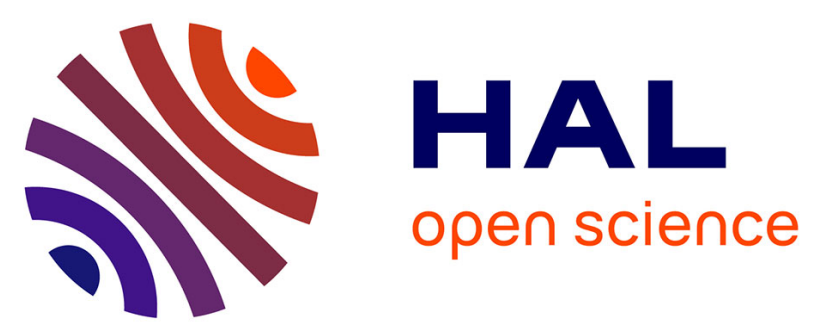

\title{
Book Review: Leslie Topp, James E. Moran and Jonathan Andrews (eds) (2007) Madness, Architecture and the Built Environment. Psychiatric Spaces in Historical Context (New York: Routledge). Pp xii + 346, 39 Illus. $£ 65.00$. ISBN 0-415-37529-0 \\ Susan Piddock
}

\section{To cite this version:}

Susan Piddock. Book Review: Leslie Topp, James E. Moran and Jonathan Andrews (eds) (2007) Madness, Architecture and the Built Environment. Psychiatric Spaces in Historical Context (New York: Routledge). Pp xii $+346,39$ Illus. £65.00. ISBN 0-415-37529-0. History of Psychiatry, 2008, 19 (3), pp.382-384. 10.1177/0957154X080190030805 . hal-00570925

\section{HAL Id: hal-00570925 \\ https://hal.science/hal-00570925}

Submitted on 1 Mar 2011

HAL is a multi-disciplinary open access archive for the deposit and dissemination of scientific research documents, whether they are published or not. The documents may come from teaching and research institutions in France or abroad, or from public or private research centers.
L'archive ouverte pluridisciplinaire HAL, est destinée au dépôt et à la diffusion de documents scientifiques de niveau recherche, publiés ou non, émanant des établissements d'enseignement et de recherche français ou étrangers, des laboratoires publics ou privés. 
Leslie Topp, James E. Moran and Jonathan Andrews (eds) (2007) Madness, Architecture and the Built Environment. Psychiatric Spaces in Historical Context (New York: Routledge). Pp xii $+346,39$ Illus. £65.00. ISBN 0-415-37529-0.

As someone with a particular interest in the built environments of lunatic asylums, I was looking forward to reading this book, for it promised to offer insights into an area of asylum history - the internal world of the lunatic asylum - that is only just beginning to be considered by researchers. I was not disappointed. This volume, with its multi-disciplinary approach, offers much. The editors' stated goal is not to resuscitate the reputation of asylum space, but rather to 'seek to contribute to an understanding of these buildings and spaces as complex social, cultural, and medical phenomena' (p. 2). This is done by presenting a range of articles that deal with asylum buildings, built environments, spatial arrangements and space (in all its connotations), drawing on the skills of historians, historical geographers, sociologists and architects. The articles range from straightforward histories and building analyses to more theoretical approaches to space and madness, and reflect the intention of the book to consider not just purpose-designed buildings but other spatial settings, built and 'natural', rural and urban (p. 4).

The book is divided into six parts. The first, 'Madhouses, asylums and hospitals in context', focuses on the architecture and form of asylums, both physically and in terms of space and spatial arrangements. Jane Kromm explores sculptural decoration and the spatial experience of Dutch asylums of the sixteenth and seventeenth centuries, and presents a fascinating insight into these places and the views held about asylum space. Leonard Smith focuses more on architectural aspects by looking at the locations, exteriors and interiors of asylums designed between 1750 and 1820, and interestingly discusses the original placement of these early asylums in the landscape near hospitals.

The second part, 'Case studies in psychiatric space', offers articles on the York Retreat, Broadmoor Asylum, and Inverness District Asylum, all in the UK. Barry Edington's contribution on the York Retreat and its influence on the West Riding Lunatic Asylum addresses Quakerism and its effect on William Tuke's thinking and design for The Retreat, and the role played by 'designing for health' (p. 90). Unfortunately, the article does not provide a convincing argument for The Retreat's supposed influence on later asylum design, since it lacks a depth of detail. By contrast, in his article on the Inverness District Asylum, Chris Philo brings to bear the skills of a historical geographer in considering how different spatial scales - in this case, regional context and the inner space of the asylum - can provide different focuses and information, which in turn can inform wider questions. Particularly interesting are the patients' views of the asylum and its setting, and an area 
not often discussed by researchers but one that is important to patients: the role of the institution as a sanctuary and place to alleviate loneliness.

The third part, 'Beyond the institution', addresses communities for the insane. Thomas Mueller analyses the spread of the community care concept, as exemplified by the Gheel colony's influence on the systems and models of family care for the mentally ill in France and Germany. James Moran then presents a most interesting study of informal community care for the insane in New Jersey by looking at lunacy trial documents and the effects of lunatic asylums' construction upon this care. The fourth part explores 'Race and space in colonial asylums'. Sally Swartz, in an article that considers space as a theoretical concept rather than a physical space, the provisions for black people and seamen in South Africa compared with those made for the white population. Waltraud Ernst offers a similar consideration of the provisions for white Europeans and Indian natives, and argues that social, economic, caste and religious factors made the provision of care more complex in India than the obvious 'ruler and ruled' dichotomy.

The fifth part, 'Architects and institutions', offers studies of German, Austrian and English asylum architecture, while the final part, 'Spatial players: professionals and patients', provides two very different articles. Kerry Davies' study of modern patients in Oxfordshire, England, provides a fascinating insight into the patient experience of place and space - both private and public - as well as their movement through the hospital. The final article by Kai Sammet looks at the world of German asylums, with a focus on the role of internal visibility in the control and observation of patients and staff.

The heart of this book is its consideration of psychiatric spaces, architecture and built environments. From this launch point the book presents one of the most diverse collections of articles on asylums, from their earliest manifestations in the sixteenth century right through to modern twentieth-century hospitals. It travels the globe with articles from Europe to the European colonies of India and South Africa. The book is in effect a sampler of the diverse range of techniques and questions that can form a part of lunatic asylum studies, and it allows the reader to explore ideas and topics drawn from the diverse range of disciplines that the authors represent. The diversity of the book makes it an important contribution to the field as it significantly expands our knowledge of the complexity of ideas that informed the designs, roles and experiences of the lunatic asylum environment. It also provides important insights into why the lunatic asylum was almost universally adopted as one of the primary means of dealing with the insane within society, despite widely differing histories and cultures between the different countries.

One of the greatest strengths of this book is its readability. Most of the articles can be easily understood, and the reader does not have to be knowledgeable about architecture, asylum history or a particular country's history to understand the arguments presented here. The writing standard is in 
general good, although one or two articles which deal with more theoretical ideas could have benefited from a clearer structure or greater clarification. Overall, this is a book well worth reading, and through the diverse range of ideas and histories presented, it offers the potential to become both a useful teaching resource and a reference book in its widest definition.

SUSAN PIDDOCK Flinders University, South Australia 